\title{
THE PRINCIPLE OF EQUAL RIGHTS
}

DOI: 10.47743/rdc-2018-2-0003

Mihai ȘTEFĂNOAIA

\section{Abstract}

The present study aims to underline the need for a concrete and thorough reglementation concerning the present legislation which defends and guarantees the enforcement of the rights and liberties of humans. Nonetheless, we will try to find and present modern and effective solutions in order to meet the challenges of the society as a result of the globalization and constant evolution of the technological progress, which become, most of the times, challenges of the constitutional justice. As a result of the studies and scientific research, we came to the conclusion that this situation generates the necessity of a universalization of judicial standards, the cooperation in matters of good practice for conferring common solutions to the common problems of the modern world. Therefore, we cannot but observe that the Constitutional Doctrine clarifies the notion of equal rights, claiming that all Romanian citizens, no matter the nationality, race, ethnicity, mother tongue, religious beliefs, political views, social origin or financial power, benefit, in equal terms, of all rights and liberties stipulated by the Constitution or other legal acts and can actively participate in the political, economical, social or cultural life.

Keywords: constitution; criminal law; human rights; jurisprudence; The Constitutional Court of Romania

The everlasting evolution of the society, of political, social, economical, cultural realities, has, as a consequence, the adaptation of the law to these new situations. Therefore, some laws are rejected or modified, completed, as a result of the influence and social interventions, trying to keep up with the evolution of the society and imposing, eventually, that the criminal and constitutional law to be adapted to what the social, political economical realities of the society mean. We observe that at least one thing remains unaltered: the respecting of the principles of the Fundamental Law. Starting from these principles, the Romanian Constitution, even if, throughout the years has suffered significant or less significant modifications, has been "forced" to ensure the presence of the principles in its core, principles through which to guarantee the

${ }^{1}$ Associate Professor, PhD, "Petre Andrei” University of Iasi. 


\section{Mihai ŞTEFĂNOAIA}

respecting of the fundamental human rights and liberties, which are only present and applied in a functional and real State Law.

At present, the principle of equality, principle which is to be found at the basis of all law systems, states that "all citizens must be equal in front of the law and public authorities, with no privileges or discrimination" and that "no one is above the law". In the countries with a democratic tradition, the existence and respecting of this principle represents, in fact, a fundamental principle of the Law System and, in equal terms, an important behavioral social trait.

Therefore, for the beginning, one can observe that a definition of this principle has already been formulated, a definition that can easily be found at art. 16 from the Romanian Constitution. At the same article we can also find stipulated the way in which the public, civil and military functions and dignities can be occupied: "The public, civil, and military functions and dignities, can be occupied, in terms of the law, by the people who own the Romanian citizenship and live within the borders of the country, " and by which the Romanian state guarantees the equality of chances between women and men for the occupation of public functions and dignities, and, at the same time, the right of every citizen who meets the requirements of the law to elect or be elected within the public local and central administration: "The Romanian state guarantees the equality of opportunity between women and men for the occupation of these functions and dignities. In regard to the adherence of Romania to the European Union, the citizens who meet the requirements of the Organic Law, have the right to elect and be elected in the authorities of the local public administration."

At the same time, the principle which represents the main target of the present scientific study is guaranteed by the Romanian Constitution by the same art. number 16: "The principle of equal rights is stipulated by the Romanian Constitution".

As a result, as we have shown above, he equal rights represents principle that can be found in the Constitution of Romania at art. 16. The text of the law comprises general stipulations that can be applied to any citizen: (1) All citizens are equal in front of the law and public authorities, without any privileges and discrimination. (2) No one is above the law; moreover, the equal rights is manifested in particular cases, which refer to the occupation of public functions and titles, as such: (3) "Public functions and dignities, civil or military, can be occupied, by rules of the law, by people who own Romanian citizenship and live in the country. The Romanian state guarantees the equality of chances between men and women for the occupation of these functions and dignities"2.

These stipulations are corroborated with others mentioned in the Constitution, which involve the equal rights principle. For example: art. 4 entitled "The Unity of the People and the Equality among Citizens" alin. (2), which forbids discrimination; art. 6 which stipulates the right to identity; art. 38 which refers to "The Right of Being Elected

2 The Constitution of Romania, republished in the Official Monitor nr. 767 from 31 st October 2003, art. 16.

\section{CONSTITUTIONAL LAW REVIEW}


in the European Parliament"; art. 41 entitled "Work and Social Protection of Work", art. 44 "The Right to Private Property, which will be dealt in a further chapter of the paper", art. 56 which stipulates the social contributions of the citizens, which must be just; art. 62, which deals with the election of the Houses of Parliament.

The Constitutional stipulations are completed by a series of documents ratified by international organizations, such as:

- The Universal Declaration of Human Rights, which in art. 1 says that "all human beings are born free and equal in rights and dignity";

- The Convention for defending the fundamental rights and liberties - ratified by art. 14 forbidding the discrimination, which means that obeying the rights and liberties of the individual established by law is a right which "must be guaranteed without any difference, based especially on gender, race, color, language, religion, political opinions or any other opinions, national or social origin, belonging to a national minority, wealth, birth or any other situation";

- The Carta of fundamental rights of the European Union- stipulates the principle of equality of all people "equality in front of the law, the no discrimination; cultural, religious and linguistic diversity; the equality between men and women; the rights of the children; the rights of old people; the integration of handicapped people".

The Constitutional Doctrine clarifies the notion of equal rights, claiming that all Romanian citizens, no matter the nationality, race, ethnicity, mother tongue, religious beliefs, political views, social origin or financial power, benefit, in equal terms, of all rights and liberties stipulated by the Constitution or other legal acts and can actively participate in the political, economical, social or cultural life.

Taking into account the stipulations of art. 16 alin. 1 from the Constitution of Romania, together with those of art. 4, The Constitutional Court has decided, related to the meaning of the principle of equality, the following:

- "the principle of equal rights in front of the law means that all people must be treated the same in situations which are not different and a different approach cannot but be only the express view of the legislator, but must be justified rationally and objectively"3;

- "the principle of equal rights means, on the one hand, unitary regulation and nondiscriminatory treatment for identical situations and, on the other hand, implies a right to differentiate" ${ }^{4}$;

\footnotetext{
3 The CCR decision no. 15 from 20 june 2006 regarding the unconstitutionality exception of the stipulations of art. 161 from the law no. 51/1995 for the organization and manifestation of the profession of lawyer, published in the Official Monitor, no. 598 on 11 July 2006.

${ }^{4}$ The CCR decision no. 1092 from 15 October 2008 regarding the unconstitutionality notice of the law for the modification and completion of law no. 19/2000 regarding the public pension system andother social rights, published in the Official Monitor, no.712 on 20 October.
}

STUDIES AND ARTICLES 


\section{Mihai ŞTEFĂNOAIA}

- the principle of equal rights deals with not only people or citizens, but also legal entities who have confronted with a differentiated judicial treatment" 5 .

Prior to the revision of the Constitution, the reglementation concerning the holding of public functions and dignities stipulated that all aspirants must hold the Romanian citizenship. After this enterprise and as a consequence to the adherence to the European Union, combined with the foreknowledgement of art. 40 from the Carta of Fundamental Rights of the European Union, it was stipulated through art. 16 alin.4 from the Constitution of Romania that "the citizens of the European Union who meet the requirements of the organic law have the right to elect or be elected in the authorities of local public administration". Of all these rights, in equal terms, women also benefit. The Carta of Fundamental Rights of the European Union, supports through art. 23 the equality between women and men: "The equality between women and men must be supported in all fields, including the working field, jobs and remuneration. The principle of equality does not exclude the maintaining or adoption of regulations which to sustain the specific advantages in favour of the under- represented gender" 6 .

The practical application of the constitutional principle of equality represents, in fact, respecting the stipulations of the Constitution. "Regardless it is considered an objective law principle or a subjective fundamental right, it is expressed through a series of values - a couple which have already become common place, strict equality (relative equality, formal equality), material equality, equality in front of the law, equality through law"7.

The Constitution of Romania regulates through art.16 the general principle of equality. Analyzing the text of the law, we deduce that, the before mentioned principle refers to a formal judicial equality and not to an equality of conditions. Taking this into account, we can state that the legislator establishes that the equality in front of the law and public authorities does not mean uniformization, meaning that the same principle cannot be applied to all citizens, without taking into consideration the specific features of each and every individual. The complexity which characterizes the principle of equality is revealed by the very judicial content. That is why, if the existence of some similar judicial situations demand the application of some equal judicial treatments, it is the very principle of equality which asks for a different approach when the situations are different. To put it in other words, the legislator establishes equal judicial solutions for equal or different situations, when the situation of the implied parties are different. From this point of view, the specialty literature, presents the term of positive discrimination, seen, as a matter of fact, as a way to ensure social protection. Regarding the limits of the constitutional principle of equality, the jurisprudence of the

\footnotetext{
5 The CCR decision no. 512 from 18 November 2004 regarding the unconstitutionality exception of the stipulations of art. 172, alin. 2 from the Goverment Enactment no. 92/2003 regarding the Fiscal Procedure Code, published in the Official Monitor, no. 1246 on 23 December 2004.

6 The Carta of Fundamental Rights of the European Union, art. 23.

${ }^{7}$ S.E. Tănăsescu, The principle of equality in Romanian Law, Ed. All Beck, Bucharest, 1999, page 3.
} 
Constitutional Court indicate the existence of some judicial solutions which vary between a strict equality, sometimes associated with the principle of nondiscrimination, and a relative equality, an equality which accepts the differentiation of the judicial regime, according to the objective features of the concrete situations" ${ }^{\prime 8}$.

The Constitutional Court, in its jurisprudence, interprets the concept of discrimination and, respectively, that of privileges. In his respect, it was shown that breaking the principle of equality in rights draws the breaking of the constitutional regulations which refer to these concepts. The Constitutional Court saw that "the discrimination is based on the notion of being expelled from a right and the specific constitutional remedy in the case of noticing the unconstitutionality of the discrimination is represented by granting or giving access to the benefit of law". The Constitutional jurisprudence defines the privilege as "an advantage or an unjustified favour given to a person or a category of people. In this case, the unconstitutionality of the privilege does not equal the granting of this benefit to all people or some category of people, but with the limitation of the privilege granted unjustifiably". The constitutional instance mentions that the phrase "without privileges and discriminations" from art. 16 alin 1 from the Constitution takes into consideration two distinctive theories, and the incidence of one or another implies different constitutional law sanctions" 9 .

There has also been found in the jurisprudence of the Constitutional Court that "the situations in whichsome category of people can be found must differ essentially so as to justify the difference in judicial treatment, and this difference must be based on an objective and rational criterion"10.

According to the formulations from the jurisprudence of the Constitutional Court, the strict equality in front of the law means that in the case of identical situations, equal solutions must be applied, with no discrimination. But, we can also find that some disagreements in some situations imposes a different judicial treatment, which implies the principle of proportionality. This principle is ratified by art. 53 alin. 2 from the Constitution and is applicable to the cases in which, because some exceptional situations the state faces, some serious breaking of rights and fundamental liberties. The limitations or the conditioning brought to some fundamental rights and liberties take form inside the constitutional text which regulates them, just because they are so normal, representing, at the same time, a constant of the fundamental rights. The mechanism regulated in art. 53 from the Constitution is triggered in the case of the appearance of a certain "situation" which caused the confinement (alin. 2 of art. 53), which means that when in the political, economical, social or cultural life of the state an

\footnotetext{
${ }^{8}$ S.E. Tănasescu, The principle of equality in Romanian Law,Ed. All Beck, Bucharest, 1999, page 17.

9 The CCR decision, no. 755 from 16 December 2014, published in the Official Monitor of Romania, Part I, no. 101 on 9 February 2015.

10 The CCR decision, no. 266 from 25 June 2014, published in the Official Monitor of Romania, Part I, no. 644 on 2 September 2014.
} 


\section{Mihai ŞTEFĂNOAIA}

incompatible break appears with the common exercise of the law content of fundamental rights and liberties, such a situation in which a temporary legislative endeavor does not depend on the person s behavior, but it is independent of it ${ }^{11}$.

In this context, a test of proportionality will be held, sui generis, and in this respect, the analyzed text indicates not only the purpose but also the necessary and proportional character of the confinement. The proportional character expresses, mainly, an idea of temporality, whose significance consists in the fact that the confinement of the exercise of fundamental rights/liberties will stop the moment in which the situation which generated it, on its turn, stopped. Secondly, it searches for a restrained proportionality, which means respecting a law of balance, known being the fact that a confinement of the exercise of a right or liberty becomes a fulfilment in a higher degree of the exercise of fundamental rights/liberties or of a principle which is in competition with ${ }^{12}$.

The reception of the principle of proportionality, of German origin, in the jurisprudence of the Constitutional Court of Romania must be accompanied by a thorough application in order not to alter the purpose and its purposefulness, that of creating and maintaining a balance between the rights/liberties and the competitive constitutional principles. Therefore, it can be asserted that the principle of equality is not respected in the cases in which similar situations are solved differently or when in different situations the same treatment is applied ${ }^{13}$. Another way through which the principle of equality can be broken is represented by the cases in which different solutions given to similar judicial situations is not based on objective or rational reasons or if the unequal treatment does not fully serve the purpose for which the respective law was given.

The very jurisprudence of the Constitutional Court reflects the constitutionality of the application of different judicial solutions, for different judicial situations and even admits the importance of respecting the right of being treated differently ${ }^{14}$. The Constitutional Court stated that "a difference of judicial treatment is inadmissible on social or functioning criteria, because this would mean a discrimination"15. It has been stated that "there can be situations which can permit particularities, but not any case as such justifies a difference in judicial treatment, especially when a different treatment like this would represent a discrimination".

\footnotetext{
11 The CCR decision, no. 712 from 4 December 2014, regarding the unconstitutionality exception of the stipulations of art 211-217 from the Criminal Procedure Code, published in the Official Monitor, no. 33 on 15 January 2015.

12 M.-M. Pivniceru, K. Benke (2015), Receptarea principiului proporționalității în jurisprudența Curții Constituționale a României. Influențe constituționale germane, in Revista de Drept Constituțional Nr. 1/2015, Editura Universul Juridic, București, p. 66.

13 M.-M. Pivniceru, K. Benke (2015), Receptarea principiului proporționalității în jurisprudența Curții Constituționale a României. Influențe constituționale germane, in Revista de Drept Constituțional Nr. 1/2015, Editura Universul Juridic, Bucureşti, p. 71.

${ }^{14}$ I. Muraru, M. Constantinescu, Curtea Constituțională a României, Ed. Albatros, București, 1997, p. 113.

15 The CCR decision nr. 6/1993, published in the Official Monitor, Part I, nr. 61 from 25 March 1993.
} 
The constitutional instance showed that respecting the principle of equality in rights does not have the significance of the reflection in the judicial norm of a full uniformity of social situations, but, on the contrary, the diversity of all social situations can be altered by the legislator proportionally, so as to bring them to a common factor ${ }^{16}$. Therefore, the specialists in law state, opinion with which we also agree upon, the rejection of the uniformity and the obligativity of differentiating the judicial treatment, in the case of the existence of situations considered distinct, objectively, do not constitute discrimination, and are valued in the jurisprudence of the Constitutional Court ${ }^{17}$. By means of the jurisprudence, the Supreme instance from our country supports the implementation of the principle of equality on the grounds that all the citizens have the right to be treated equally in front of the law and public authorities, and, under no circumstances the application of different judicial treatments for a certain category of people is to be accepted. Starting from the premises that the fundamental rights "represent o constant in the personality of the citizen, an equal chance given to any individual, "art. 16, alin. 1 from the republished Constitution grants the equality between the citizens regarding all the rights that all should benefit from, equally, all individuals, as it is stipulated in the legislative domain, and not the identity of the judicial treatment, without taking into account the nature of the situations. In this respect, the Constitutional Court supports "the constitutionality of the administration of a different judicial treatment for certain categories of people, but not the necessity of such a judicial treatment"18.

The same idea has been mentioned in jurisprudence through other decisions of the Constitutional Court, which consider that the regulation of a sanctionatory regime depending on how the prejudice was covered by the committed crime is the natural expression of the constitutional principle of equality, which stipulates that in the same judicial situations the same treatment to be applied, and in different judicial situations, a different treatment to be applied ${ }^{19}$. The behaviour of the people under charges who can have a contribution to the finding of the truth in some situations is a situation which demands for a different treatment. This represents an act of criminal law policy, determined by the occurrence of some severe anti-social phenomena which impose the necessity of the enforcement of special measures, which are not to harm the principle of equality ${ }^{20}$. The Constitutional Court is of the opinion that the stipulation of a different judicial treatment for two different situations in which the crime of theft was done, cannot be interpreted as discrimination because the legislator stated, clearly and

\footnotetext{
16 The CCR decision, no. 349 from 2013, published in the Official Monitor of Romania, Part I, no. 708 on 19 November 2013.

17 M. Andreescu, C. Andreescu (2018), Interferența între principiile constituționale ale egalității şi proporționalității - semnificații juridice şi implicații sociale, in Dreptul Nr. 5/2018, p. 71.

18 The CCR decision, no. 213 from 2004, published in the Official Monitor of Romania, Part I, no. 519 on 9 June 2013 and the decision no. 240/2004 published in the Official Monitor of Romania, Part I, no. 562 on 24 June 2004.

19 The CCR decision, no. 1214 from 2010, published in the Official Monitor of Romania, Part I, no. 808 on 3 December 2010.

20 The CCR decision, no. 636 from 2010, published in the Official Monitor of Romania, Part I, no. 398 on 16 June 2010.
} 


\section{Mihai ŞTEFĂNOAIA}

objectively, the criterion of importance of the social value. For example, we can bring into mind the decision of the Constitutional Court regarding the existence of the "discrimination between the people who commit the crime of theft and who benefit from the chance to reconciliation, as a way to erase the criminal liability and the people who commit the crime of stealing trees". The supreme instance has stated that the differentiated treatment is justified on the reason that there are two different judicial situations which "have at their basis the objective criterion of the importance of the social value defended by the incrimination norm, the national forest fund representing a national interest good"21.

In conclusion, as a result of the scientific study and research, we came to the belief that this situation generates the necessity for a universalization of the judicial standards in the field, the cooperation in matters of good practice in order to offer common solutions to common problems of the modern world, and last but not least, to the acknowledgement of the importance of the constitutional control both a priori and $a$ posteriori.

The Constitutional control includes "the observation of the basic conditions of the well being of the documents of the authorities of the state", which translates into the conformity of the law with the Constitution. Therefore, it is stated that the constitutional control represents a means of guaranteeing the supremacy of the Constitution. The legislative field establishes very clearly who is the authority to verify the constitutionality and what steps are to be followed after.

The constitutional control is applied at international level, too, by means of the stipulations of the national constitutions, related to the international relations.

"The internal dimension of the constitutional control means the respecting of the constitution within the limits of the state".

The consequence, on external plan, resides in the ensuring of the respecting of the international norms. The Constitutional control in the case of the states members of the European Union is accomplished by adapting to the national constitutional norm and not to the EU ones.

At the same time, we show that, for the safety of the enforcement of the application and respecting of the current judicial norms, the principle of equal rights being included, the integration of the constitutional jurisprudence at the basis of the law, indicate what the specialists have named "the passage towards juristocracy", which means the tendency to transfer power from the representative public authorities, to the judicial ones, which is also beneficial and is to be encouraged.

In this respect, one can easily notice that the decisions regarding human rights belong, more and more often to the national and supranational constitutional courts. As a consequence, it can be inferred that we can now refer to the extinction of the constitutionalization of the law in global terms, which means the assimilation at national level, of the jurisprudence established by international courts.

21 The CCR decision, no. 293 from 2015, published in the Official Monitor of Romania, Part I, no. 436 on 18 June 2015. 